\title{
Antimicrobial Activity of some Egyptian Citrus Peels Extracts
}

Ghada M. Kholaf ${ }^{1}$, Emad G.Gomaa ${ }^{2}$ and Hamid M. Ziena ${ }^{1}$

\begin{abstract}
Citrus juice production generates 15 million tons of wastes a year in the world, including peels, seeds and fruit pulps. This study aimed to evaluate the antimicrobial activity of extracted essential oils from six Egyptian citrus fruit peels. This antimicrobial activity was determined by paper disc diffusion method against six fungal strains and nine bacterial strains. Maximum inhibition zones were resulted against Penicillium sp and Aspergillus niger CAIM 147 with oils of lime and lemon peels which were extracted by hydrodistllation. In addition, the lime oil was more effective on fungal strains than lemon oil. The results showed also that oils of mandarin, sour orange and sweet orange peels extracted by the same method did not show any antifungal activity on the all tested fungi. While grapefruit peel extract has moderate effect on some fungal and bacterial growth. Also these essential oils of lime and lemon peels had very strong antibacterial activity on Bacillus subtilis DBDR 100, Clostridium botulinum ATCC 3584, Escherichia coli CCM 5172, Klebsiella pneumonia ATCC 12296 and Salmonella senftenbergy ATCC 8400. The essential oils extracted by organic solvents from all citrus fruit peels used in the present work were moderate weak activity against tested fungi and bacteria. The obtained results agreed with the phenolic contents in the essential oils extracted from citrus fruit peels and the results showed that increasing of phenolic content in these oils increased the diameter of inhibition zones of the all tested fungi and bacteria. The results showed that the lime peel oil extracted by hydrodistillation $(10 \mu \mathrm{l})$ was more effective and completely inhibited the growth of $A$. niger and Penicillium $s p$ compared with lemon peel oil. Different concentrations of oil lime extracted by hydrodistllation were more effective against bacterial strains activities compared to lemon oil. B. subtilis was more sensitive at low concentration $(10 \mu \mathrm{L})$ of lime oil followed by $K$. pneumonia and $S$. senftenbergy at $30 \mu \mathrm{L}$ under the same conditions. And $\mathrm{E}$. coli and $\mathrm{Cl}$. botulinum were more resistant with lime oil until 50 and $40 \mu \mathrm{L}$ of lime oil, respectively. On the other hand, $20 \mu \mathrm{L}$ of lemon peel extracted by hydrodistillation completely inhibited the growth of $B$. subtilis, while the minimum inhibitory concentration (MIC) of oil lemon peel was $30 \mu \mathrm{L}$ for $K$. pneumonia and $S$. senftenbergy, $40 \mu \mathrm{L}$ for $E$. coli and $50 \mu \mathrm{L}$ for $\mathrm{Cl}$. botulinum. Accordingly, the essential oils of lime and lemon peels extracted by hdrodistllation contained antimicrobial compounds which can be used as preservatives in the food industries.
\end{abstract}

Keywords: Citrus peel extract, antimicrobial activity, hydrodistillation, extraction, phenolic content.

${ }^{1}$ Department of Food and Dairy Science \& Technology, Faculty of Agriculture, Damanhour University, Damanhour, 22516, Egypt

${ }^{2-}$ Department of Food Sci. \& Tech., Faculty of Agriculture,

El- Shatby, Alexandria University, Alexandria, Egypt

Received Novmber 20,2017, Accepted December 27, 2017

\section{INTRODUCTION}

Citrus is the largest fruit worldwide, as its annual production is approximately 100 million tons. The main world producers are Mediterranean countries and USA (Djilas, 2009 \& Ghafar et al., 2010). There are great varieties of citrus species (about 40 species) which can be classified as follows; Orange-fruit types [sweet orange, sour orange \& mandarin] and Yellow-fruit types [lemon, lime \& grapefruit] (Schotter et al., 2002 \& Karimi et al., 2012). Citrus fruits are mainly used in food industries for fresh juice production which generate approximately 15 million tons of citrus wastes a year worldwide. These wastes include peels, seeds and fruit pulps (Sanz-Puig et al., 2016) and consider as a source of environmental pollution. Citrus peels are the main by-product during processing, which represented in some citrus varieties about half of the fruit mass (Negro et al., 2016).

The use of chemical or synthetic agents as antimicrobial activity is one of the oldest techniques for controlling microorganism's growth. The application of food preservatives is fundamental if their safety is to be maintained (Viuda-Martos et al., 2008). The synthetic fungicides are found to be problematic due to their residual nature and high toxicity to mammals (Chen et al., 2008). So a shift from synthetic chemicals to botanical antimicrobial is gaining popularity because of their environmental safety (Varma and Dubey, 1999). Citrus peel oils from different plant source can inhibit various pathogenic bacteria, and total phenolic compounds and limonoids are highly correlated with antibacterial activity (Gorinstein et al., 2001 \& Radha $e t$ al., 2014).

Roy et al. (2012) reported that citrus fruits are mainly used by juice proceeding industries, while the peels as by-products, which are rich in nutrients and contain many phyto-chemicals, can be efficiently used as drugs, food supplements. Among natural antimicrobials, the effect of essential oils extracted from many plants and fruits are discussed as antimicrobial additives (L?pez-Malo et al., 2000; Angioni et al., 2003, Feng and Zheng, 2007 \& Viuda-Martos et al., 2008). 
Essential oils of citrus peels have been searched for their antifungal and antimicrobial properties (Bendaha et al., 2016). Literature existing on the antimicrobial activities of lime oil, states its potent antibacterial (Aibinu et al., 2007) and antifungal effects (BarreraNecha et al., 2009 \& Razzaghi- Abyaneh et al., 2009), as it has several medicinal properties and potential health benefits which make it good natural antimicrobial preservatives in food products.

Essential oils obtained from citrus peels are complex mixture of some compounds such as hydrocarbons, alcohols, esters, aldehydes and have been reported to exhibit inhibitory activities against wide spectrum food spoilage microorganisms (Uysal et al., 2011). The bacteriostatic and bactericidal capacities of citrus byproducts could be significantly due to their polyphenol content. Numerous studies showed that citrus peels contain many bioactive compounds which have antioxidant and antimicrobial properties (Ghafar et al., 2010 \& Dhanavade et al., 2011).

Shan et al. (2007) observed that the effect of phenolic compounds as an antimicrobial activities can degrade the cell wall, disrupt the cytoplasmic membrane, cause leakage of cellular components, change fatty acid, influence DNA and RNA synthesis, and destroy protein translocation of bacteria (Huang and Chung, 2003). These phenols and phenolic compounds are extensively used in disease preventions and remain the standard when compared with other bactericides or fungicides (Okwu, 2003 \& 2005 and Okwu \& Morah, 2007).

The peels are an interesting source of phenolic compounds which include phenolic acids and flavonoidas, also and monoterpenes hydrocarbons, exhibiting antimicrobial activities in several foods ( Cushnise and Lamb, 2005). Therefor, a large amounts of citrus peels are used every year for production of essential oils as good source of phenolic compounds, pectin and limonene (Anwar, 2008), and also are used as flavouring agent in candies, carbonated and noncarbonated beverages, bakery products, ice-cream cakes and biscuits and also as inhibitor of varies microorganisms (Siddique et al., 2011). On the other side, Jafari et al. (2011) added essential oils of lime for reducing microbial population of cream-filled cakes and pastries.

The present study aimed to investigate the antimicrobial activity of essential oils extracted from six Egyptian citrus fruit peels against six fungal strains and nine bacterial strains which cause food spoilage, poisoning or infection.

\section{Citrus Fruit Samples:}

Six citrus fruit varieties grown in Egypt were used in the present study namely; Grapefruit (Citrus paradisi Mac Fdyen) [GF], Lemon (Citrus Limon) [LE], Lime (Citrus aurantifolia Swingle) [LI], Mediterranean mandarin (Citrus reticulata Blanco) [MM], Sour orange (Citrus aurantium) [SOO] and Sweet orange (Citrus sinensis L. Osbeck) [SWO]. These samples were obtained at the mature stage from a local supermarket in Alexandria, Egypt, from December 2015 to February 2016.

\section{Preparation of Extracts:}

Citrus extractions from all the studied citrus fruits were obtained from two sources. Frist one was hydrodistillation method from the fresh surface layer (flavedo) of citrus fruit peels. The second source was extraction from the dried peels powder using three separately solvents: ethanol, hexane and Folch solution (chloroform: methanol 2:1 V/V).

Hydrodistillation method was used for extraction of essential oils from fresh surface outside layer (flavedo) of citrus fruit peel according to Shukla et al. (2009) with some modifications as follow: $300 \mathrm{ml}$ of distilled water were added to $100 \mathrm{~g}$. sample and were subjected to hydrodistillation using distillate apparatus at $70^{\circ} \mathrm{C}$ for $3 \mathrm{hr}$. After collection about $70 \mathrm{ml}$ distillate, the upper layer containing essential oils was collected by micropipette. The trace water was removed using nitrogen gas, then stored at $4^{\circ} \mathrm{C}$ in sealed glass bottles for using in the experiment as antimicrobial and for determination of the phenolic content.

Ethanol extraction was carried out according to Yadav et al. (2004). Dried peel powder (10 g. of 9 mesh) from each citrus fruit variety was separately mixed with $30 \mathrm{ml}$. of absolute ethanol. The mixtures were placed in sealed glass bottles at room temperature for $24 \mathrm{hr}$. with continuous stirring. Also, $50 \mathrm{ml}$ of Folch solution was used for extraction of essential oils from $10 \mathrm{~g}$. of dried peels powder according to Folch et al. (1957). On the other hand, the same amount of each sample was mixed with $50 \mathrm{ml}$. hexane in sealed glass bottles at room temperature and shaked for $24 \mathrm{hr}$.

The extractions were then filtered through Whatman No 1 filter paper. Then, the filtrates were concentrated by using rotary evaporator until removing all the organic solvents. The concentrated essential oils of peel samples were stored in sealed glass bottles at $4^{\circ} \mathrm{C}$ until used in the present work. All obtained essential oils were weighted to determine the yield $(\%)$ and colours.

\section{MATERIALS AND METHODS}

\section{Determination of total phenolic content:}


The total phenolic content of the essential oils extracted from the studied citrus fruit peel samples were determined by Folin- Ciocalteu reagents(Singleton and Rossi, 1965), using spectrophotometer Optizin-UV-Vis spectrophotometer (model Thermo Electron Corporation, Korea). Gallic acid calibration standard with concentration of $0,5,10,20,40,60$ and $80 \mu \mathrm{g} / \mathrm{ml}$ in $50 \%(\mathrm{v} / \mathrm{v})$ methanol was prepared. The results were expressed as percentage of gallic acid on dry weight basis.

\section{Maintenance of fungal and bacterial strains:}

Six culture strains of fungi were used in the present study namely; Aspergillus flavus ATCC 5517, Aspergillus niger CAIM 147, Aspergillus niger DSM 731, Aspergillus oryzae NRRL 9362, Penicillium sp and Rhizopus sp. Potato dextrose agar (PDA) medium was used for maintenance of these fungal strains (Difco Manual, 1984). The PDA slants were inoculated with culture and incubated at $30^{\circ} \mathrm{C}$ for $72 \mathrm{hr}$., then slants were maintained under sterilized paraffin oil as stock cultures.

Also, nine culture bacterial strains were used in the present work included: Bacillus subtilis DBDR 100, Clostridium botulinum ATCC 3584, Escherichia coli CCM 5172, Escherichia coli DSM 1576, Klebsiella pneumonia ATCC 12296, Salmonella senftenbergy ATCC 8400, Staphylococcus aureus NCTC 10783, Staphylococcus epidermdia and Staphylococcus pyogenes. These bacteria were grown on slant plate count agar (PCA) recommended by Oxiod Manual (1982), then incubated at $37^{\circ} \mathrm{C}$ for $24 \mathrm{hr}$. and maintained at $-40^{\circ} \mathrm{C}$ until used.

The fungal strains were grown on PDA medium at $30^{\circ} \mathrm{C}$ for 7 day for complete sporulation. The spores suspension were obtained from slant agar with $10 \mathrm{ml}$ of $0.1 \%$ sterilized peptone water, then many dilutions were made for enumeration of spores suspension. The number of fungal spores present in the suspension was determined by indirect technique for cell count (De Moss and Bard, 1957). The number of spores from suspension solution was $28-33 \times 10^{7} / \mathrm{ml}$.

The same technique was used for enumeration of bacterial colonies forming unit (CFU/ml) using the PCA medium. The numbers of bacterial colonies in suspension solution were $840-880 \times 10^{2} \mathrm{CFU} / \mathrm{ml}$ for $\mathrm{Cl}$. botulinum \& S. senftenbergy and 768-780x $10^{2} \mathrm{CFU} / \mathrm{ml}$ for B. subtilis \& K. pneumonia, while E. coli CCM 5172 was $544 \times 10^{2} \mathrm{CFU} / \mathrm{ml}$.

\section{Antimicrobial Assay (Diffusion method):}

The antimicrobial potential of essential oils from citrus peels was evaluated by paper disc diffusion (Hussain et al., 2011 \& Efstratiou et al., 2012). One ml of fungal strains suspension was added to Petri dishes containing liquefied PDA medium $\left(45-50^{\circ} \mathrm{C}\right)$. Also one $\mathrm{ml}$ of bacterial strains suspension was inoculated in PCA medium. After solidify these media, filter paper disc (Whatman No 3, 4 diameters) containing $10 \mu \mathrm{l}$ of each essential oils were put on the surface of media. The essential oils of citrus peels were used as a positive control, while paper discs with respective sterile water or organic solvents was taken as a negative control. The plates containing PDA and PCA were incubated at $28^{\circ} \mathrm{C}$ for $48 \mathrm{hr}$. and $37{ }^{\circ} \mathrm{C}$ for $24 \mathrm{hr}$., respectively. The diameter of inhibition zones (DIZ) around paper discs were recorded $(\mathrm{mm})$. Duplicate studies were performed for each sample.

The results of this experiment showed that the maximum inhibition effects were recorded for essential oils of LI and LE peels extracted by hydrodistillation, on all fungal and bacterial strains used in the present work.

\section{Determination of minimum inhibitory concentration (MIC):}

To achieve the best minimum inhibitory concentration (MIC) extracted of essential oils from LI and LE peels by hydrodistillation at different concentrations (10-60 $\mu \mathrm{l})$ were added to sterilized media, then $1 \mathrm{ml}$ of each fungal and bacterial suspension were inoculated in each plate and incubated as mentioned previously.

The lowest concentration of LE and LI essential oils, which showed no fungal or bacterial growth, defined as MIC. Every test was performed by duplicate.

\section{Statistical analysis method:}

The data were analyzed using the Statistical Analysis System software package (SAS, 2000). Analyses of variance were performed using ANOVA procedures. Significant differences between mean were determined using Duncan's multiple range test.

\section{RESULTS AND DISCUSSION}

\section{Yield and colour of essential oils:}

The essential oils, extracted by steamhydrodistillation from fresh peels of all studied citrus fruits, were colourelss (transparent colour), while the essential oils extracted from dried peels by organic solvents ranged between pale- yellow to orange colour.

The yields obtained from these peels by hydrodistillation were about 10.7 to $12.6 \mathrm{ml} / \mathrm{kg}$ of dried peels. The amount of extracts by organic solvents ranged between 15.2 to $20.4 \%$. These results are in agreement with Sekar, et al. (2013), who found that nature colours of methanol extracts from dried peels of lime (Citrus aurantifolia), lemon (Citrus limon), mandarin (Citrus reticulate) and sweet orange (Citrus 
sinensis) were light green, light yellow, dark green and dark orange, respectively, and the percentage yields from these dried peels were 12.84, 17.26, 21.56 and $18.38 \%$, respectively. Fejzić and Ćavar (2014) reported that the yields isolated with ethanol from peels ranged from 4.91 to $7.44 \%$ for orange and white grapefruit, respectively. Sultana et al. (2015) found that the extract of Citrus limon peels with aqueous methanol content was $9.44 \mathrm{~g}$. per $100 \mathrm{~g}$. dried peels. Also the obtained results by Bendaha et al. (2016) showed that essential oils isolated by hydrodistillation from peels of sour orange (C. aurantium) and also Soxhelt hexane extract from the same dried peels, were fragrant colourless and the yield ranged between 1.04 to $4.50 \%$.

\section{Total phenolic contents:}

The percentage of total phenolic content of the essential oils of citrus fruit peels extracted by hydrodistillatin and three organic solvents are presented in Table (1). The results showed that LI and LE peel oils which extracted by hydrodistillation gave phenolic content higher than the other samples (3.31 and 2.84\%, respectively), followed by GF $(2.51 \%)$. Also the phenolic content in isolated extract of LI by using each of hexane and Folch gave 2.16 and $2.05 \%$, respectively, and GF ethanolic extract was $2.01 \%$. On the other hand, the essential oils extracted by hydrodistillation and the other three organic solvents from peels of MM, SOO and SWO contained lower percentage of phenolic content compared with other oils of peel samples. The lowest levels of phenolic content found in SWO peel oils $(0.67 \%)$ which extracted by hydrodistillation and also in isolated extracts of SOO $(0.68 \%)$ and SWO $(0.71 \%)$ by using Floch method. From these results, it can be concluded that the content of phenolic compounds is generally higher in oils of LI and LE peels which extracted by hydrodistillation.

According to available literatures data about citrus fruit peels, there are certain differences in the results. In the study of Okwu et al. (2007) who extracted oils from citrus peel samples by Soxhlet apparatus with diethyl ether, they found that phenolic content of lemon $C$. limonum peel oil was the highest $(0.64 \%)$ followed by grapefruit $C$. vitis $(0.56 \%)$ and lime $C$. aurantifolia $(0.47 \%)$. While the peel oil of mandarin $C$. reticulata was lower $(0.23 \%)$ than those in other oils extracted from citrus fruit peels. Ghasemi et al. (2009) reported that the highest content of phenolics extracted by methanol from the orange peel was $232.5 \mathrm{mg}$ GAE/g. While the lowest content was found in lemon peel (102.2 mg GAE/g). Guimar?es et al. (2010) determined the phonolics expressed as mg GAE /g extract of the essential oils isolated from fresh citrus peels by hydrodistillation. They found that the highest phenolic amount was in lime peel oil (124.63) followed by lemon (87.77) and orange (79.75), while grapefruit oil gave the lowest amount of content as phenolics, it was 55.88 mg GAE/g extract. Fejzić and Ćavar (2014) expressed the percentage of total phenolic content in extracts of citrus peels with ethnol. They found that their content in extracted peels of lemon, orange, mandarin and white grapefruit were $0.89,0.61,0.49$ and $0.39 \%$, respectively. Irkin et al. (2015) determined the content of total phenolics as $\mathrm{mg} \mathrm{GAE} / \mathrm{g}$ in some citrus peels which were extracted by $80 \%$ aqueous methanol. They found that the grapefruit, orange and mandarin peels were rich in phenolic compounds (13.71, 11.08 and $9.31 \mathrm{mg} \mathrm{GAE} / \mathrm{g}$, respectively). While lemon peel contained 5.35 phenolic content expressed as $\mathrm{mg}$ GAE/g. Also Sultana et al. (2015) used the same method for isolation of the extract from $C$. limon peel. They found that the total phenolic content was 158.79 $\mathrm{mg} / \mathrm{g}$ dry matter. Molan et al. (2016) used four different solvents for extraction of total phenolic content from Iraqi sweet orange peels. They found that maximum total phenolic content was $53.1 \mathrm{mg}$ GAE/g dry weight by using $5 \% \mathrm{HCl}$ and this value decreased by using boiling water (38.4) followed by $50 \%$ ethanol (25.9), while using cold water the total phenolic content was $15.1 \mathrm{mg}$ GAE/g dry weight. These differences of phenolic content might be due to numerous factors, including types of extraction, kind of solvents ,climatic variables, growing environment, plant age and harvesting time as well as the origin of the sample (Douglas et al., 2004 \& Duffy et al., 2009).

\section{Antimicrobial assay:}

The antimicrobial assay included two methods. The first was diffusion method for measurement of the diameter of inhibition zone (DIZ) of each fungal and bacterial strains used in the present study as effected by essential oils of the studied peels. The second method namely; microbial count was to achieve the minimum inhibitory concentration (MIC) of essential oils from citrus peels on growth of fungal and bacterial strains.

\section{Disc diffusion method:}

Table (2) showed the antifungal activity of the different oil extracts of citrus fruit peels $(10 \mu \mathrm{l})$ against fungal strains growth. The results illustrated that the inhibition of each fungal strains growth by hydrodistillation extracts of GF, LE and LI were the best compared to essential oils extracted with ethanol, hexane and Folch method but in different levels of diameter of inhibition zone.

Essential oils of MM, SOO and SWO peels obtained by hydrodistillation, ethanol and Folch extracts have not any inhibition effect on all the studied fungi. While hexane extract has weak effect inhibition on these fungi. 
Same results were found, as Penicillium $s p$ was the most inhibited fungi by LI peel extracted by hydrodistillation as it recorded $20 \mathrm{~mm}$ DIZ compared with ethanol, hexane and Folch extracts (14, 9 and 12 $\mathrm{mm}$ DIZ, respectively). While Rhizopus $s p$ has the lowest effect by Folch and hexane (DIZ were 4 and 5 $\mathrm{mm}$, respectively). But the GF and LE peel oils hadn't any effect on Rhizopus $s p$.

The results in Table (2) showed that essential oil of LI peels extracted by hydrodistillation was also highly effective on growth prevention of A. niger CAIM 147 as it recorded DIZ $18 \mathrm{~mm}$ followed by $A$. oryzae NRRL $9362(16 \mathrm{~mm})$. Also the extracted oil of LE peels has the lesser effect on Penicillium sp and A. niger CAIM 147 compared with LI peel oil (DIZ were 10 and 12 $\mathrm{mm}$, respectively). Mahmud et al. (2009) extracted the essential oil of sour lime peels by hydrodistillation and studied the effect of this oil against the growth of different fungal strains by disc diffusion method. They found that DIZ after $48 \mathrm{hr}$. of incubation period was
$16.5 \mathrm{~mm}$ with A. niger and $10 \mathrm{~mm}$ of Penicillium digitulum. These results are in accordance with the results obtained in the present study (Table).

The results in Tables (1) and (2) indicated that phenolic compounds in essential oil of LI, LE and GF peels which extracted by hydrodistillation have the highest effect on fungal inhibited zone. Also these results showed that essential oils of LI and LE peels extracted by the same method had the highest percentage of phenolic contents compared with the other essential oils peels rather than those extracts which were more effective on fungal growth and have larger inhibition zones.

Also Table (1 and 2) showed that the essential oils of MM, SOO and SWO peels extracted by hydrodistillation, ethanol and Floch had lower amount of phenolic contents and did not show any inhibition effect on all fungal growth.

Table 1. Phenolic content $(\%)$ of essential oils extracted from citrus fruit peels

\begin{tabular}{|c|c|c|c|c|}
\hline \multirow{2}{*}{ Species of citrus fruits } & \multicolumn{4}{|c|}{ Phenolic content (\%) } \\
\hline & Hydrodistillation* & Ethanol $^{*}$ & Hexane $^{*}$ & Folch* \\
\hline Citrus paradisi (GF) & $2.51 \pm 0.01^{\mathrm{c}}$ & $2.01 \pm 0.02^{\mathrm{a}}$ & $1.61 \pm 0.01^{\mathrm{c}}$ & $1.56 \pm 0.01^{c}$ \\
\hline Citrus limon (LE) & $2.84 \pm 0.03^{b}$ & $1.76 \pm 0.01^{\mathrm{c}}$ & $1.66 \pm 0.01^{\mathrm{b}}$ & $1.75 \pm 0.01^{\mathrm{b}}$ \\
\hline Citrus aurantifolia (LI) & $3.31 \pm 0.02^{\mathrm{a}}$ & $1.94 \pm 0.01^{\mathrm{b}}$ & $2.16 \pm 0.03 \mathrm{a}$ & $2.05 \pm 0.02^{\mathrm{a}}$ \\
\hline Citrus reticulata (MM) & $0.97 \pm 0.01^{\mathrm{d}}$ & $0.86 \pm 0.03^{\mathrm{d}}$ & $1.25 \pm 0.02^{\mathrm{d}}$ & $0.76 \pm 0.01^{\mathrm{d}}$ \\
\hline Citrus aurantium (SOO) & $0.87 \pm 0.01^{\mathrm{e}}$ & $0.87 \pm 0.02^{\mathrm{d}}$ & $1.11 \pm 0.01^{\mathrm{e}}$ & $0.68 \pm 0.02^{\mathrm{e}}$ \\
\hline Citrus sinensis (SWO) & $0.67 \pm 0.02^{\mathrm{f}}$ & $0.86 \pm 0.02^{\mathrm{d}}$ & $0.91 \pm 0.01^{\mathrm{f}}$ & $0.71 \pm 0.03^{\mathrm{e}}$ \\
\hline
\end{tabular}

* Extraction methods.

-The data are means \pm standard deviation of duplicate determination on dry weight basis.

-Values with the same superscript in each column are not significantly different at $p<0.05$.

Table 2. Antifungal activity of the different extracts of citrus fruit peels $(10 \mu \mathrm{L})$ against fungal strains.

\begin{tabular}{|c|c|c|c|c|c|c|c|c|c|c|c|c|}
\hline \multirow{3}{*}{ Fungal strains } & \multicolumn{12}{|c|}{ Diameter of inhibition zone (DIZ mm) } \\
\hline & \multicolumn{6}{|c|}{ Hydrodistillation $^{* *}$} & \multicolumn{6}{|c|}{ Ethanol $^{* *}$} \\
\hline & GF & LE & LI & MM & SOO & SWO & GF & $\mathrm{LE}$ & LI & MM & SOO & SWO \\
\hline Aspergillus flavus $\quad$ ATCC 5517 & 9 & 9 & 15 & - & - & - & 4 & 1 & 11 & - & - & - \\
\hline A. niger CAIM 147 & - & 12 & 18 & - & - & - & 2 & 2 & 5 & - & - & - \\
\hline A. niger DSM 731 & 8 & 8 & 13 & - & - & - & 3 & 3 & 8 & - & - & 3 \\
\hline A. oryzae NRRL 9362 & 7 & 9 & 16 & - & - & - & 6 & 2 & 8 & - & - & - \\
\hline Penicillium sp. & 7 & 10 & 20 & - & - & - & 4 & 4 & 14 & - & - & - \\
\hline \multirow[t]{2}{*}{ Rhizopus sp. } & - & 9 & 12 & - & - & - & 6 & 3 & 5 & - & - & - \\
\hline & \multicolumn{6}{|c|}{ Hexane } & \multicolumn{6}{|c|}{ Folch ${ }^{*}$} \\
\hline Aspergillus flavus $\quad$ ATCC 5517 & - & 1 & 7 & 1 & 1 & - & 1 & - & 14 & - & - & - \\
\hline A. niger CAIM 147 & 5 & 2 & 8 & 3 & 2 & 1 & - & 5 & 4 & - & - & - \\
\hline A. niger DSM 731 & - & 2 & 4 & 3 & 2 & 4 & - & 2 & 8 & - & - & - \\
\hline A. oryzae NRRL 9362 & 9 & 5 & 11 & 8 & 5 & - & - & - & 10 & - & - & - \\
\hline Penicillium sp. & - & 1 & 9 & 3 & 1 & 3 & 3 & 2 & 12 & - & - & - \\
\hline Rhizopus sp. & - & - & 5 & - & - & - & - & - & 4 & - & - & - \\
\hline
\end{tabular}

GF: Grapefruit, LE: Lemon, LI: Lime, MM: Mediterranean Mandarin, SOO: Sour Orange, and SWO: Sweet orange.

*Diameter of inhibition zone (DIZ) including disc paper diameter of $4 \mathrm{~mm}$.

*** Extraction method.

- Not inhibited zone 
On the other hand, the essential oils of MM, SOO and SWO peels extracted by hexane contained phenolic compounds higher than those obtained by the other organic solvents (Table 1), and the results in Table (2) showed the effect of hexane extracts on fungal inhibition zones.

Huang and Chung (2003) reported that phenolic compounds from plant extracts caused swelling of hyphal trips, plasma seeping around hyphae, leaking of plasma, cell well distortion and consequently wrinkling of hyphae surface.

Okwu et al. (2007) extracted oil from five citrus peels and found that lemon peels was the highest phenol content followed by grapefruit and lime. They added that the increment of phenolic content in these oils increased the inhibition growth of Fusarium oxyspoium.

Accordingly, the essential oils extracted from LE and LI peels by hydrodistillation were the most effective on inhibition of each Penicillium $s p$ and A. niger CAIM 147. So, these oil extracts and two these fungal strains were selected to continue this study.

Table (3) showed the effect of different essential oils extracted from citrus fruit peels on bacterial activity expressed by DIZ. The disc papers were saturated with $10 \mu \mathrm{l}$ of these oils.

The obtained data revealed that the essential oils extracted by hydrodistillation from LI and LE peels have the highest antibacterial activity compared with all tested microorganisms used in the present work followed by GF peel extract, but in different levels of DIZ. LI, LE and GF peels extracted by ethanol, hexane and Floch had weak activity against growth on all the studied bacteria. Also the essential oils of MM, SOO and SWO peels extracted by hydrodistillation, ethanol, hexane and Floch did not show any effect on growth of some tested bacteria. The results in Table (3) indicated that essential oils from LE and LI peels extracted by hydrodistillation were very effective on growth of all tested bacteria except E. coli DSM 1576, Staph. epidermdia and Staph. pyegenes. In addition, the essential oil from LE peels was more effective on growth of other tested bacteria compared with the essential oil of LI peels. The data showed that DIZ of essential oils of LI and LE peels extracted by hydrodistillation recorded, respectively, Bacillus subtilis (13, $12 \mathrm{~mm})$, Cl. botulinum (18, $13 \mathrm{~mm})$, E. coli CCM 5172 (14, $13 \mathrm{~mm})$, K. penumonia $(18,13 \mathrm{~mm})$ and $S$. senftenbergy $(18,11 \mathrm{~mm})$. While the lowest DIZ recorded 5, $7 \mathrm{~mm}$ with Staph. aureus. On the other hand, the growth of E. coli DSM 1576 was already known to be multi-resistance for the extracted essential oils from MM, SOO and SWO peels. Also Staph. aureus, Staph. epidermdia and Staph. pyogenes were uninhibited by hydrodistillation extracted oil of both SOO and SWO peels. These results may be due to their low content of phenolic compounds.

The results in this study showed moderate values comparing with those reported by Mahmud et al. (2009), who found that DIZ of discs impregnated with $0.45 \mathrm{ml}$ of extracted essential oils of sour lime peels has high antibacterial activity on Bacillus subtilis $(22 \mathrm{~mm})$, S. typhimarium $(17 \mathrm{~mm})$. But the values of DIZ were 18 $\mathrm{mm}$ for Staph. aureus and $6 \mathrm{~mm}$ for E. coli. Roy et al. (2012) found that maximum DIZ of E. coli was $10 \mathrm{~mm}$ compared with Staph. aureus $(8 \mathrm{~mm})$ when used volatile oils extracted from lemon peels by hydrodistillation. Hindi and Chabuck. (2013) studied the effect of aqueous extract of lemon peels against six Gram-positive and eight Gram-negative bacteria, then measured the DIZ by using $20 \mu \mathrm{l}$ from aqueous extract. They found that DIZ of $K$. peneumoniae was $20 \mathrm{~mm}$, while $E$. coli has not any zone of inhibition. Bendaha et al. (2016) used $10 \mu \mathrm{l}$ of essential oil of sour orange peel (C. aurantium) isolated by steam hydrodistillation with paper disc. They found the DIZ was $10 \mathrm{~mm}$ with Staph. aureus, while the E. coli DH5 was resistant to this essential oil. These results disagreed with the obtained results in the present work. This may be due to variation of variety of genus of bacteria, also kinds of citrus fruits and different extraction methods.

According to the results in Tables (1) and (3), the essential oils of LI and LE peels extracted by hydrodistillation contained high percentage of phenolic compounds, so they have strong effect on bacterial growth compared with the other extracts. From these obtained results, each of $\mathrm{B}$. subtilis DBDR 100, $\mathrm{Cl}$. botulinum ATCC 3584, E. coli CCM 5172, $K$. pneumonia ATCC 12296 and S. senftenbergy ATCC 8400 were highly sensitive by essential oils of LI and LE peels extracted by hydrodistillation methods. So, these bacteria were used for identification of minimum inhibitory concentration of LI and LE essential oils extracted by hydrodistillation.

\section{Minimum inhibitory concentration of LI and LE peel oils:}

The present study examined the effect of adding extracted LI and LE peel oils at different concentrations ranged between $10-60 \mu \mathrm{l} / \mathrm{ml}$ to growth media of two fungal strains and five bacterial strains to detect the minimum inhibitory concentration (MIC) caused completely growth inhibition of these fungal and bacterial strains. 

Table 3. Antibacterial activity of the different extracts of citrus fruit peels $(10 \mu \mathrm{L})$ against bacterial strains

\begin{tabular}{|c|c|c|c|c|c|c|c|c|c|c|c|c|}
\hline \multirow{3}{*}{ Bacterial strains } & \multicolumn{12}{|c|}{ Diameter of inhibition zone (DIZ mm $\left.{ }^{*}\right)$} \\
\hline & \multicolumn{6}{|c|}{ Hydrodistillation $^{* *}$} & \multicolumn{6}{|c|}{ Ethanol $^{* * *}$} \\
\hline & GF & LE & LI & MM & SOO & SWO & GF & LE & LI & MM & SOO & SWO \\
\hline Bacillus subtilis DBDR100 & 9 & 12 & 13 & 10 & 9 & - & 6 & 2 & 7 & 3 & 2 & 1 \\
\hline Clostridium botulinum ATCC 3584 & 7 & 13 & 18 & 9 & 9 & - & 4 & 1 & 10 & - & 1 & - \\
\hline Escherichia coli CCM 5172 & 4 & 13 & 14 & - & 9 & 10 & 3 & - & - & - & 1 & - \\
\hline Escherichia coli DSM 1576 & 8 & 7 & 11 & - & - & - & 6 & - & 5 & - & 2 & - \\
\hline Klebsiella pneumonia ATCC 12296 & 9 & 13 & 18 & - & 10 & - & 5 & 2 & 5 & 1 & 5 & - \\
\hline Salmonella senftenbergy ATCC 8400 & 5 & 11 & 18 & 7 & - & 11 & 3 & 1 & 3 & 2 & 4 & 2 \\
\hline Staphylococcus aureus NCTC 10783 & 9 & 5 & 7 & 7 & - & - & 6 & 2 & 3 & - & - & - \\
\hline Staphylococcus epidermdia & 7 & 9 & 7 & 9 & - & - & - & 3 & 3 & - & - & - \\
\hline \multirow[t]{2}{*}{ Staphylococcus pyogenes. } & 10 & 4 & 10 & 10 & - & - & - & 4 & 4 & - & - & - \\
\hline & \multicolumn{5}{|c|}{ Hexane $^{* *}$} & \multicolumn{7}{|c|}{ Folch $^{* * *}$} \\
\hline Bacillus subtilis DBDR 100 & 3 & 3 & 6 & 3 & 4 & 3 & 7 & 4 & 7 & 4 & 1 & 1 \\
\hline Clostridium botulinum ATCC 3584 & 2 & 2 & 4 & 2 & 1 & - & 2 & 1 & 2 & 5 & - & - \\
\hline Escherichia coli CCM 5172 & - & 3 & - & - & 2 & - & - & 1 & - & 1 & - & - \\
\hline Escherichia coli DSM 1576 & - & - & 5 & 3 & - & - & 2 & 5 & 3 & 1 & - & - \\
\hline Klebsiella pneumonia ATCC 12296 & 2 & 2 & 5 & 5 & 5 & 3 & 4 & 3 & 3 & 3 & 2 & 4 \\
\hline Salmonella senftenbergy ATCC 8400 & - & 1 & 3 & 1 & 1 & 3 & 2 & 3 & 5 & 1 & - & 5 \\
\hline Staphylococcus aureus NCTC 10783 & - & 2 & - & 2 & - & - & - & - & - & 1 & - & - \\
\hline Staphylococcus epidermdia & - & 3 & 3 & 1 & - & 2 & 3 & - & 2 & 2 & 3 & 1 \\
\hline Staphylococcus pyogenes. & 2 & 1 & 5 & 4 & - & 2 & 4 & 4 & 4 & 5 & 2 & - \\
\hline
\end{tabular}

GF: Grapefruit, LE: Lemon, LI: Lime, MM: Mediterranean Mandarin, SOO: Sour Orange, and SWO: Sweet orange.

*Diameter of inhibition zone (DIZ) including disc paper diameter of $4 \mathrm{~mm}$.

${ }^{* *}$ Extraction method.

- Not inhibited zone.

Table 4. Effect of different concentrations of hydrodistillation extracts of lime and lemon peels on enumeration of fungal strains

\begin{tabular}{|c|c|c|c|}
\hline \multirow{3}{*}{ Strains } & \multirow{3}{*}{$\begin{array}{c}\text { Concentrations } \\
(\mu \mathrm{l})\end{array}$} & \multirow{2}{*}{\multicolumn{2}{|c|}{$\begin{array}{c}\text { CFU/ml. } \\
\text { Hydrodistillation extracts }\end{array}$}} \\
\hline & & & \\
\hline & & Lime peels (LI) & Lemon peels (LE) \\
\hline \multirow{5}{*}{$\begin{array}{l}\text { Aspergillus niger } \\
\text { CAIM } 147\end{array}$} & 0 & $285 \times 10^{6}$ & $285 \times 10^{6}$ \\
\hline & 10 & 0.0 & $250 \times 10^{6}$ \\
\hline & 20 & 0.0 & $24 \times 10^{6}$ \\
\hline & 30 & 0.0 & $20 \times 10^{6}$ \\
\hline & 40 & 0.0 & 0.0 \\
\hline \multirow{9}{*}{ Penicillium $s p}$. & 50 & 0.0 & 0.0 \\
\hline & 60 & 0.0 & 0.0 \\
\hline & 0 & $325 \times 10^{6}$ & $325 \times 10^{6}$ \\
\hline & 10 & 0.0 & $150 \times 10^{6}$ \\
\hline & 20 & 0.0 & $60 \times 10^{6}$ \\
\hline & 30 & 0.0 & 0.0 \\
\hline & 40 & 0.0 & 0.0 \\
\hline & 50 & 0.0 & 0.0 \\
\hline & 60 & 0.0 & 0.0 \\
\hline $\begin{array}{l}\text { Table (4) showed the effect } \\
\text { of LI and LE peel oils on en } \\
\text { CAIM } 147 \text { and Penicillium } \\
\text { growth of } A \text {. niger at } 10 \mu 1 \text { of }\end{array}$ & $\begin{array}{l}\text { ntrations } \\
\text { A. niger } \\
\text { owed no } \\
\text { the same }\end{array}$ & \multicolumn{2}{|c|}{$\begin{array}{l}\text { concentration of LE oil, the count was } 250 \times 10^{6} \mathrm{CFU} / \mathrm{ml} \\
\text { on the same conditions. But at } 40 \mu \mathrm{l} \text {, the growth } \\
\text { completely stopped. Increasing the concentration of LE } \\
\text { oil, the count of } A \text {. niger decreased. On the other hand, }\end{array}$} \\
\hline
\end{tabular}


the results indicated that $10 \mu \mathrm{l}$ of LI oil has the same effect on Penicillium sp, while addition of $30 \mu \mathrm{l}$ of LE oil to medium completely inhibited the growth of Penicillium sp. So, the LI peel oil had higher effect on the two tested fungal strains than LE peel oil. Also Penicillium $s p$ was the most susceptible at $30 \mu \mathrm{l}$ of LE oil, while MIC of $A$. niger was $40 \mu$ l under the same conditions.

The data in Table (5) represented that using $10 \mu \mathrm{l}$ of LI peel oil was completely inhibited the growth of $B$. subtilis. While using the same concentration of this oil reduced the count of $K$. pneumonia and $S$. senftenbergy from initial inoculums from $780 \times 10^{2}$ to $200 \times 10^{2}$ $\mathrm{CFU} / \mathrm{ml}$ and $880 \times 10^{2}$ to $400 \times 10^{2} \mathrm{CFU} / \mathrm{ml}$, respectively. Also, addition of $20 \mu \mathrm{l}$ from this oil to media was more effective and prevented the growth. The results showed that $E$. coli was more resistant with LI oil until $40 \mu \mathrm{l}\left(25 \times 10^{2} \mathrm{CFU} / \mathrm{ml}\right)$, while the MIC was $50 \mu \mathrm{l}$. Also the viable count of $\mathrm{Cl}$. botulinum was 49 $\mathrm{x} 10^{2} \mathrm{CFU} / \mathrm{ml}$ at $30 \mu \mathrm{l}$ of LI oil, while no viable count was observed at $40 \mu \mathrm{l}$ under the same conditions. The same Table revealed that $B$. subtilis was highly sensitive at $20 \mu \mathrm{l}$ oil of LE peels. This level was the MIC for growth of $B$. subtilis.

Table 5. Antibacterial activity of different concentrations of hydrodistillation extracts of lime and lemon peels

\begin{tabular}{|c|c|c|c|}
\hline \multirow{3}{*}{ Strains } & \multirow{3}{*}{$\begin{array}{l}\text { Concentrations } \\
\qquad(\mu \mathrm{l})\end{array}$} & \multicolumn{2}{|c|}{ CFU/ml. } \\
\hline & & \multicolumn{2}{|c|}{ Hydrodistillation extracts } \\
\hline & & Lime peels (LI) & Lemon peels (LE) \\
\hline & 0 & $768 \times 10^{2}$ & $768 \times 10^{2}$ \\
\hline & 10 & 0.0 & $692 \times 10^{2}$ \\
\hline Bacillus subtilis & 20 & 0.0 & 0.0 \\
\hline \multirow[t]{6}{*}{ DBDR 100} & 30 & 0.0 & 0.0 \\
\hline & 40 & 0.0 & 0.0 \\
\hline & 50 & 0.0 & 0.0 \\
\hline & 60 & 0.0 & 0.0 \\
\hline & 0 & $840 \times 10^{2}$ & $840 \times 10^{2}$ \\
\hline & 10 & $320 \times 10^{2}$ & $640 \times 10^{2}$ \\
\hline Clostridium botulinum & 20 & $111 \times 10^{2}$ & $440 \times 10^{2}$ \\
\hline \multirow[t]{6}{*}{ ATCC 3584} & 30 & $49 \times 10^{2}$ & $384 \times 10^{2}$ \\
\hline & 40 & 0.0 & $196 \times 10^{2}$ \\
\hline & 50 & 0.0 & $84 \times 10^{2}$ \\
\hline & 60 & 0.0 & 0.0 \\
\hline & 0 & $544 \times 10^{2}$ & $544 \times 10^{2}$ \\
\hline & 10 & $112 \times 10^{2}$ & $172 \times 10^{2}$ \\
\hline Escherichia coli & 20 & $72 \times 10^{2}$ & $120 \times 10^{2}$ \\
\hline \multirow[t]{6}{*}{ CCM 5172} & 30 & $48 \times 10^{2}$ & $56 \times 10^{2}$ \\
\hline & 40 & $25 \times 10^{2}$ & $38 \times 10^{2}$ \\
\hline & 50 & 0.0 & 0.0 \\
\hline & 60 & 0.0 & 0.0 \\
\hline & 0 & $780 \times 10^{2}$ & $780 \times 10^{2}$ \\
\hline & 10 & $200 \times 10^{2}$ & $468 \times 10^{2}$ \\
\hline Klebsiella pneumonia & 20 & 0.0 & $305 \times 10^{2}$ \\
\hline \multirow[t]{6}{*}{ ATCC 12296} & 30 & 0.0 & 0.0 \\
\hline & 40 & 0.0 & 0.0 \\
\hline & 50 & 0.0 & 0.0 \\
\hline & 60 & 0.0 & 0.0 \\
\hline & 0 & $880 \times 10^{2}$ & $880 \times 10^{2}$ \\
\hline & 10 & $400 \times 10^{2}$ & $560 \times 10^{2}$ \\
\hline Salmonella senftenbergy & 20 & 0.0 & $120 \times 10^{2}$ \\
\hline \multirow[t]{4}{*}{ ATCC 8400} & 30 & 0.0 & 0.0 \\
\hline & 40 & 0.0 & 0.0 \\
\hline & 50 & 0.0 & 0.0 \\
\hline & 60 & 0.0 & 0.0 \\
\hline
\end{tabular}


The effect of LE peel oil at $20 \mu 1$ which added to media of K. pneumonia and $S$. senftenbergy showed that reduction of count was from initial inoculums $780 \times 10^{2}$ to $305 \times 10^{2} \mathrm{CFU} / \mathrm{ml}$ and $880 \times 10^{2}$ to $120 \times 10^{2} \mathrm{CFU} / \mathrm{ml}$, respectively. While using $30 \mu \mathrm{l}$ from the same oil, no growth was observed completely.

The data in Table (5) showed that viable count of $E$. coli decreased with increasing LE oil from 10 to $40 \mu \mathrm{l}$. But at $50 \mu \mathrm{l}$, no growth was noted.

The results showed that $\mathrm{Cl}$. botulinum was more resistant against all concentrations of LE oil until $50 \mu \mathrm{l}$ and the viable count was $84 \times 10^{2} \mathrm{CFU} / \mathrm{ml}$. But MIC was These results showed that essential oil of LI extracted by hydrodistillation had more effect on tested bacterial strains in the present work compared with oil of LE under the same conditions. Also these results agreed with the recorded diameter of inhibition zone of each fungal and bacterial strains tested and percentage of phenolic compounds in oils extracted in the present study.

\section{REFERENCES}

Aibinu, I., T. Adenipekun, T. Adelowotan and T.Ogunsanya.2007. Evaluation of the antimicrobial properties of different parts of Citrus aurantifolia (lime fruit) as used locally. Afr. J. Trad. CAM. 4: 185-190.

Angioni, A., A.Barra, M.Arlorio and J. D. Coisson.2003. Chemical composition, plant genetic differences, and antifungal activity of the essential oil of Helichrysum italicum G. Don ssp. microphyllum (Willd) Nym. J. of Agric. and Food Chem. 51: 1030 -1034.

Anwar, F. 2008. Physico-chemical characteristics of citrus seeds and seed oils from Pakistan. J. of American Oil Chem. Society. 85: $321-330$.

Barrera-Necha, L. L., C.Garduno-Pizana and L. J. GarciaBarrera.2009. In vitro antifungal activity of essential oils and their compounds on mycelia growth of Fusarium oxysporum f sp gladioli (Massey) snyder and hansen. Plant Pathol. J. 8: 17 - 21 .

Bendaha, H., B.Bouchal, I.El-Mounsi and A. Salhi.2016. Chemical composition, antioxidant, antibacterial and antifungal activities of peel essential oils of Citrus aurantium grown in Eastern Morocco. Der Pharmacia Lettre. 8: $239-245$.

Chen, P. J., T.Moore and S.Nesnow.2008. Cytotoxic effects of propiconazole and its metabolites in mouse and human hepatoma cells and primary mouse hepatocytes. Toxicol. In Vitro. 22: 1476 -1483.

Cushnise, T. P. and A. J. Lamb.2005. Antimicrobial activity of flavonoids. Inte. J. of Antimicrobial Agents. 5: $343-$ 356.

De Moss, R. D. and R. C. Bard.1957. Manual of Microbiology Methods. MC Grow Hill Book Company Inc New York. $170-171$.
Dhanavade, M. J., C. B. Jalkute, J. S. Ghosh and K. D. Sonawane.2011. Study antimicrobial activity of lemon (Citrus lemon L.) peel extract. J. Pharmacology and Toxicology. 2: $119-122$.

Difco Manual .1984. Manual of Dehydration Culture Media and Reagent for Microbiology $\left(9^{\text {th }}\right.$ ed) Difco Laboratory. Detroit. Michigan 28232, USA.

Djilas, S. 2009. By - products of fruits processing as a source of phytochemicals. Chem. Industry and Chem. Engineering Quarterly. 15: 191- 202.

Douglas, L. A., E. I. Vartinskaya and L. P. Spear .2004. Rewarding properties of social interactions in adolescent and adult male and female rats: impact of social versus isolate housing of subjects and partners. Developmental Psychobiology J. 45: 153-162.

Duffy, k. j., G. Scopece, S. Cozzolino, M. F.Fay, R. J. Smith and J. C. Stout.2009. Ecology and genetic maculate, at the centre and edge of its range. Annals of Botany. 104: 507 516.

Efstratiou, E., A. I. Hussain, J. E.Moore, J. R. Rao, and P.Xligam.2012. Antimicrobial activity of Calendula officinalis petal extracts against fungi, as well as Gramnegative and Gram-positive clinical pathogens. Complement Ther Clin Pract. 18: 173 - 176.

Fejzić, A. and S.Ćavar. 2014. Phenolic compounds and antioxidant activity of some citruses. Bulletin of the Chem. and Technol. of Bosnia and Herzegovina. 42: 1- 4

Feng, W. and X.Zheng. 2007. Essential oils to control Alternaria alternate in vitro and in vivo. Food Control. 18: $1126-1130$.

Folch, J. M., M. Less and G. H. Stoane-Stanley.1957. A Simple method for isolation and purification of total lipids from animal tissue. J. Biol. Chem. 226: 497- 507.

Ghafar, M. F. A., K. N.Prasad, K. K.Weng and A.Ismail.2010. Flavonoid, hesperidine, total phenolic contents and antioxidant activities from Citrus species. Afr. J. of Biotechnol. 9: 326 - 330 .

Ghasemi, K., Y.Ghasemi and M. Ebrahimzadeh.2009. Antioxidant activity, phenol and flavonoid contents of 13 citrus species peels and tissues. Pak. J. Pharm. Sci. 22: $227-281$.

Gorinstein, S., O.Martin -Belloso, Y. S. Park and R. R. Haruenkit.2001. Comparison of some biochemical characteristics of different citrus fruits. Food Chem. 74: $309-315$.

Guimar?es, R., L.Barros, J. C. M.Barreira and M. J.Sousa.2010. Targeting excessive free radicals with peels and juices of citrus fruits: grapefruit, lemon, lime and orange. Food and Chem. Toxicology. 48: 99 - 106.

Hindi, N. K. K. and Z. A. G.Chabuck.2013. Antimicrobial activity of different aqueous lemon extracts. J. of Applied Pharmaceutical Sci. 3: $74-78$.

Huang, J. W. and W. C. Chung.2003. Management of vegetable crops diseases with plants extracts. Advances in Plant Disease Management. 37: 153 - 163. 
Hussain, A., F. Anwar, P. Migam and S.D. Sarker.2011. Composition, antioxtant and chemotherapeutic properties of the essential oils from two organism species growing in Pakistan. Braz. I. Pharm. 21: 943 - 952.

Irkin, R., S.Dogan, N.Degirmenioglu and M. E. Diken.2015. Phenolic content, antioxidant activities and stimulatory roles of citrus fruit on some lactic acid bacteria. Arch. Biol. Sci. Belgrade. 67: 1313 - 1321.

Jafari, S., S.Esfahani, M. R. Fazeli and H. Jamalifar .2011. Antimicrobial activity of lime essential oil against food borne pathogens isolated from cream-filled cakes and pastries. J. of Inte. Biological Chem. 10: 3923 - 3931.

Karimi, E., E.Oskoueian, R.Hendra, A.Oskoueian and H. Z. E.Jaafar.2012. Phenolic compounds characterization and biological activities of Citrus aurantium bloom. Molecules. 17: 1203 - 1218.

L?pez-Malo, A., S. M. Alzamora and S.Guerrero .2000. Natural Antimicrobials From Plants. In M. Stella, S. M. Alzamora, M. S. Tapia. and A.L?pez-Malo (Eds.), Minimally Processed Fruits and Vegetables, Fundamental Aspects and Applications pp: 237 - 363. Gaithersburg: Aspen Publishers.

Mahmud, S., M.Saleem, S.Sddique, R.Ahmed, R. Khanum and Z.Perveen.2009. Volatile components, antioxidant and antimicrobial activity of Citrus acida var. sour lime peel oil. J. of Saudi Chem. Society. 13: 195 - 198.

Molan, A. L., M. H. Ismail and R. H. Nsaif.2016. Phenolic contents and antioxidant activity of peels and seed of orange (Citrus sinensis) cultivated in Iraq. World J. of Pharmacy and Pharmaceutical Sci. 5: 473 - 482.

Negro, V., G.Mancini, B.Ruggeri, and D.Fino.2016. Citrus waste as feed stock for-based products recovery: Review on limonene case study and energy valorization. Bioresource Technol. 214: 806 -815.

Okwu, D. E. (2003). Investigation Into The Medicinal And Nutritional Potential of Garcinia kola Heckel and Demnettia tripetala G. Baker. Ph.D Thesis, Michael Okpara University of Agriculture, Umudike Nigeria, pp 4 -5 .

Okwu, D. E. 2005. Phytochemicals, vitamins and mineral content of two Nigerian medicinal plants. Inte. J. of Molecular Medicine and Advanced Sci. 1: 375 - 381.

Okwu, D. E., A.N. Awurum and J. I. Okoronkwo.2007. Phytochemical composition and in vitro antifungal activity screening of extract from citrus plants against Fusarium oxysporum of okra plant (Hisbiscus esculentus). Pest Technology. 1: 145-148

Okwu, D. E. and F. N. I. Morah.2007. Isolation and characterization of flavanone glycoside 4,5,7-trihydroxy flavanone rhamnoglucose from Garcinia kola seed. J. of Applied Sci. 7: 306 -309.

Oxoid Manual. 1982. The Oxiod Manual of Culture Media, Ingredients and Other Laboratory Services. Oxiod Limited Wade Road, Basingstoke, Hampshire RG 240 PW.
Radha, K. K., S.Babuskin, S. B. P. Azhagu and M. Sasikala.2014. Antimicrobial and antioxidant effects of spice extracts on the shelf life extension of raw chicken meat. Inte. J. of food microbial. 171: $32-40$.

Razzaghi- Abyaneh, M., M.Shams- Ghahfarokhi, M. B. Rezaee and K. Jaimand.2009. Chemical composition and antiaflatoxigenic activity of Carum carvi L., Thymus vulgaris and Citrus aurantifolia essential oils. Food Control. 20: 1018-1024.

Roy, S. D., R.Bania, J.Chakraborty and R.Goswami.2012. Pharmcognostic phytochemical, physicochemical property and antimicrobial activity studies of lemon peel oil. J. Nat. Prod. Plant Resource. 2: 431 - 435.

SAS.2000. SAS User's Guide.Version 4.02, Cary, NC, SAS Inst., USA.

Sanz-Puig, M., M. C.Pina- Pérez, A.Marthez- L?pez and D. Rodrigo.2016. Escherichia coli O157:H7 Salmonella Typhimurium inactivation by the effect of mandarin, lemon and orange by products in reference medium and in oat-fruit juice mixed beverage. J. Food Sci. and Technol. 66: $7-14$.

Schotter, P., S.Pecoroni and W. Gunnewig.2002. Separators, Decanters And Process lines for Citrus Processing, Technical - Scientific Documentation No.14 ( $2^{\text {nd }}$ Edn), Westfalia Separator AG, Germany.

Sekar, M., N.Afendi, P.Bandira and Z.Hashim.2013. Comparative evaluation antimicrobial properties of citrus varieties available in Malaysia market. Inte. J. of Current Pharmaceutical Research. 5: 32 - 35.

Shan, B.; Cai, Y. Z.; Brooks, J. D. and Corke, H. (2007). The in vitro antibacterial activity of dietary spice and medicinal herb extracts. Inte. J. of Food Microbiol., 117: 112-119.

Shukla, R., A.Kumar, P.Singh and M. K.Dubey.2009. Effect of Lippia alba (Mill) N.E. Brown essential oil and its monoterpene aldhyde constituents against fungi isolated from some edible legume seeds and aflatoxin B, production. Int. J. Food Microbiol. 135: 165 - 170.

Singleton, V. L. and J. A. Rossi.1965. Colorimetry of total phenolics with phosphomolybdic-phosphotungstic acid reagents. American J. of Enology and Viticulture. 16: 144 -158 .

Siddique, S., M.Shafique, Z.Parveen and S. J. Khan.2011. Volatile compounds, antioxidant and antimicrobial activity of Citrus aurantium var. bitter orange peel oil. Pharmacologyonline. 2: 499 - 507.

Sultana, B., F.Anwar, M. Mushtaq and M.Alim.2015. Citrus residues: a potential source of phenolic with high antioxidant values. Inte. Food Research J. 22: 1163 1168.

Varma, J. and N. K.Dubey.1999. Perspective of botanical and microbial products as pesticides of tomorrow. Current Sci. 76: 172-179.

Viuda-Martose, M.; Ruiz-Navajas, Y.; Fern?ndez-L?pez, J.; and Pérez-'Alvarez, J. 
(2008). Antifungal activity of lemon (Citrus lemon L.), mandarin (Citrus Reticulata L.), grapefruit (Citrus paradise L.) and orange (Cirtus sinensis L.) essential oils. Food Control., 19: 1130-1138.

Yadav, A. R., A. S.Chauhan, M. M.Pekha, L. J. M. Rao and R. S. Ramteke.2004. Flavor quality of dehydrated lime [Citrus aurantifolia (christm) swingle]. J. Food Chem. 85: $59-62$.
Uysal, B., F.Sozmen, O.Aktas and B. S. Oksal. 2011. Essential oil composition and antibacterial activity of the grapefruit (Citrus paradisi L.) peel essential oils obtained by solvent-free microwave extraction: comparison with hydrodistillation. Inte. J. of Food Sci. and Technol. 469: 1455 - 1461. 


\section{الملخص العربي}

\section{النشاط المضاد للميكروبات لبعض مستخلصات قشور المو الح المصرية غادة محمد خليف ، عماد الدين جمعه ، حامد مرسى زينه}

وكانت النتائج المتحصل عليها متفقة مع محتوى مستخلص قشور الزيوت العطرية من المواد الفينولية حيث

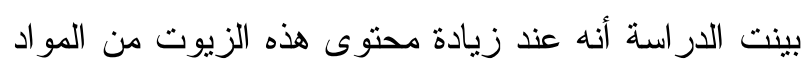

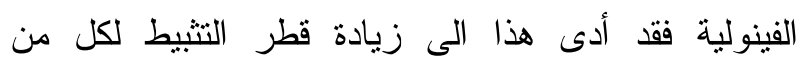

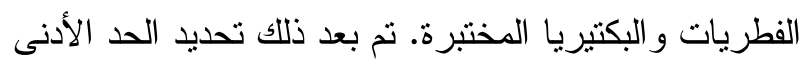

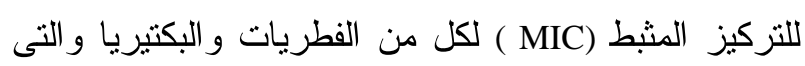
كانت ذات أكبر قطر مثبط بمستخلص التقطير المائى لكل

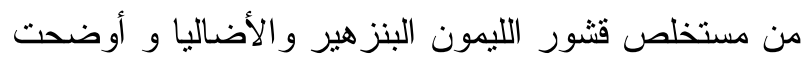
النتائج أن زيت قشور الليمون البنزهير (• ميكرولينز) كان

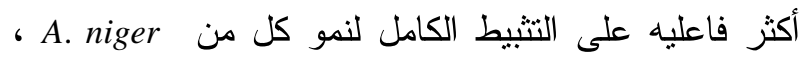
مقارنة بزيت قشور الليمون الأضاليا. كما Penicillium sp كانت B. subtilis الأكثر حساسيه لزيت قثشور الليمون

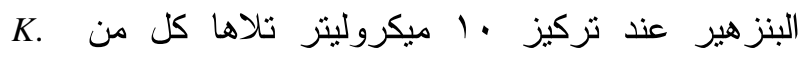
S. senftenbergy pneumonia بينما كانت كل من E. coli و الـ Cl. botulinum أكثر مقاومه و

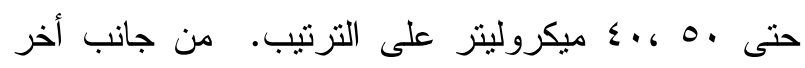

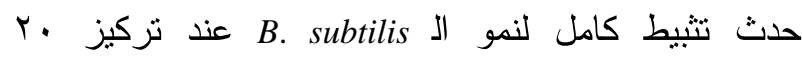
ميكروليتر باستخدام زيت قشور الليمون الأضاليا وكان الحد

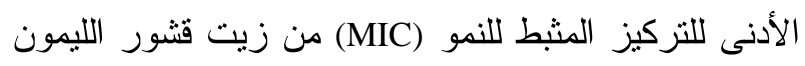

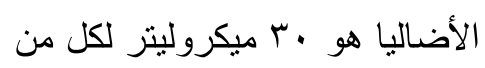

، . K. pneumonia ، S. senftenbergy

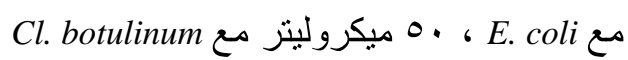

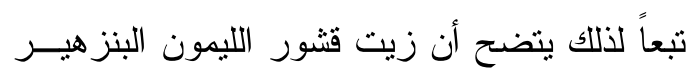

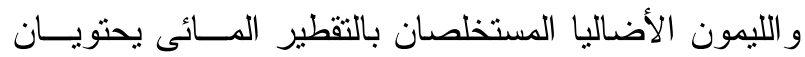
على مركبات مضادة للنمو الميكروبى ويمكن اســتخدامهما كمادة حافظه ضد الميكروبات فى مجال التصنيع الغذائى.

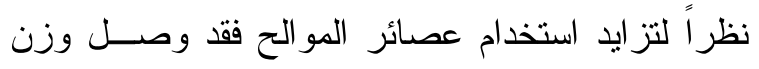
مخلفاتها عاليما إلى 10 مليون طن سنوياً، حيث شملت هذه ولث المخلفات كلا من القشور و البذور و اللب الداخلى. وقد هدفت لهن

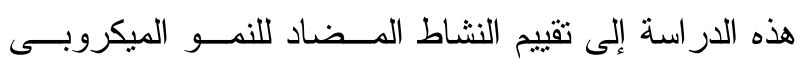

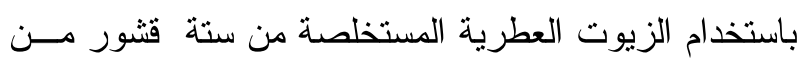
المو الح المصرية . حيث أجرى تقدير النشاط المضاد للنمو لتونه

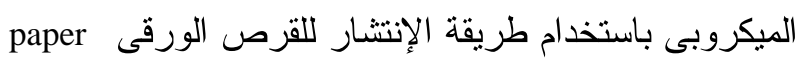
ضد ست سلالات فطرية وتسع ســلالات disc diffusion بكتيرية.

أوضحت النتائج أن الزيوت المستخلصة بالتقطير المائى من كل من قشور الليمون البنز هير و الليمون الأضاليا كانت الأكثر تثبيطاً على نمو كل من فطرى لنوى Aspergillus niger CAIM 147

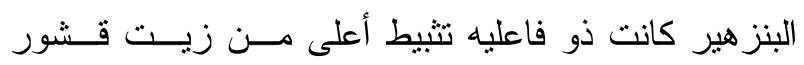

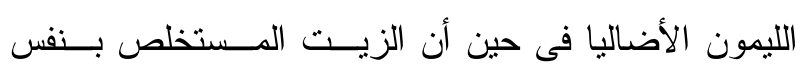

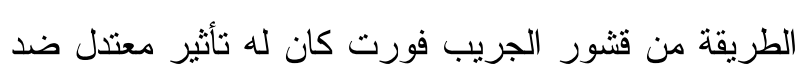

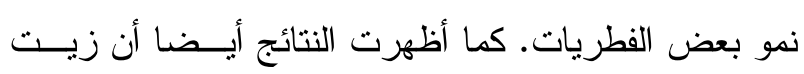

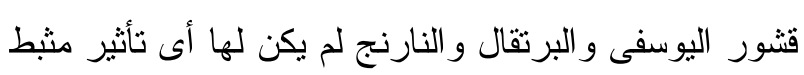

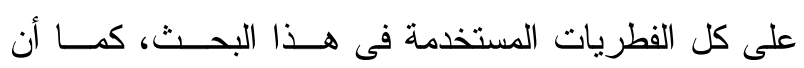

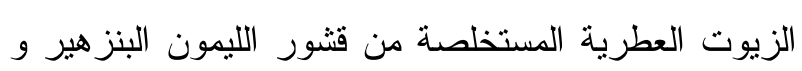

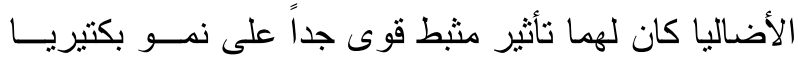
Clostridium botulinum ، Bacillus subtilis DBDR 100 Klebsiella ‘Escherichia coli CCM 5172، ATCC 3584 Salmonella senftenbergy, pneumonia ATCC 12296 بينما الزيوت المستخلصة مـن كـل قـشور 8400 الموالح باستخدام المذيبات العضوية كان لها تأثير معتدل أو لون

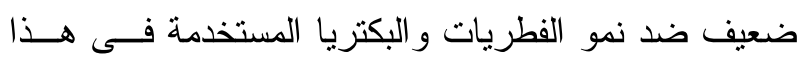

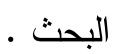



